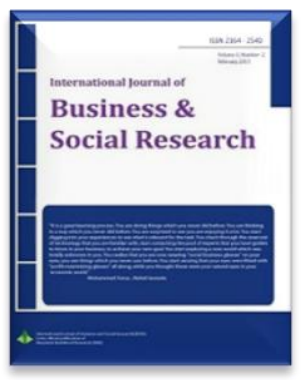

\title{
International Journal of Business and Social Research
}

Volume 07, Issue 12, 2017. 10-18

Article Received: 31-10-2017

Accepted: 14-12-2017

Available Online: 21-12-2017

ISSN 2164-2540 (Print), ISSN 2164-2559 (Online)

DOI: http://dx.doi.org/10.18533/ijbsr.v7i12.1079

\section{A Novelty in Turkish Commercial Life: Execution of QR Code on Cheques ${ }^{1}$}

\author{
Dr. Ebru TÜZEMEN ATIK²
}

\begin{abstract}
Law No. 6728 adopted on July 15, 2016 have brought changes in many laws. It has also introduced significant changes and novelties in the regulations related to cheques in the Turkish Commercial Code (TCC) No. 6102 and in the Cheque Act No. 5941. Among the most important of these changes is that the Quick Response Code (QR Code) and serial number are accepted as a compulsory form requirement for the validity of cheques. QR Code application is expected to give more credibility and prestige to cheques. In this study, the novelties introduced in cheque law with this application are discussed. The main aim of this study is to evaluate the birth and operation of the QR Code cheque system in general, from a benefits and drawbacks perspective. This study will help define this system in the international arena, take it as a model and enable the system to be developed critically. Initiating the QR Code system and accepting the QR Code as a compulsory element of cheques are a first in commercial life. For this reason, there are not enough data or studies so far in terms of the consequences of the system. However, in accordance with the purpose of its introduction, which is to fight against bounced cheques and the prevention of forged cheques, it is possible to evaluate the application of the QR Code as a convenient method at first glance.
\end{abstract}

Keywords: Cheque Leaf, Cheque, Negotiable Instruments Law, Postdated Cheque, Payment of Cheque, QR Code, Turkish Commercial Code, Turkish Commercial Law.

JEL Codes: K20, K22.

This is an open access article under Creative Commons Attribution 4.0 License, 2017.

\section{0}

\section{Introduction}

Cheque is a kind of negotiable instrument that is widely used both in national and international commercial life. In accordance with TCC Article 795/1, a cheque is paid when it is seen, and if there is a record (maturity) contrary to this on the cheque, this record is deemed not to be written. Due to its legal nature, a cheque, just like a bill, is a qualified transfer and making out a cheque enables payment to be done over the existing balance in a bank account without using cash (Öztan, 2016, pp. 218).

Due to its economic function, cheque is a payment instrument (Can, 2015; Poroy, Tekinalp, 2013; Tekinalp, 2010; Öztan, 2016). However, the use of credit cards reducing the need to make payments

\footnotetext{
${ }^{1}$ This article was presented at "4th International Annual Meeting of Sosyoekonomi Society" of Sosyoekonomi Society, in October 27-28, 2017 in Vienna, Austria. Extended abstract of this article can be also reached on Conference Proceedings Book.

${ }^{2}$ Lecturer, Karamanoğlu Mehmet Bey University, Faculty of Economic and Administrative Sciences, Department of Commercial Law, Turkey.e-mail: eatik@kmu.edu.tr, ebrutuzemen@gmail.com.
} 
with cheques, and the imposed sanctions on bounced cheques, have increased the tendency of using cheques as a credit instrument in practice (Can, 2015). Due to transactions such as futures sales, the date of issue written on cheques may be a date after the actual date of issue (For the evolution of postdated cheques and the related criticisms see Can, 2015; Çöl, 2004; Güler, 1990; Tandoğan, 1981; Tekinalp, 2002; Yasan, 2014).

Post-dated cheques has emerged as a consequence of a need arising from practice. In addition to that, Turkish law also provides protection for post-dated cheques. For instance, it has been arranged in Cheque Act No. 5941 that, in order to be able to initiate a legal follow-up on postdated cheques, a submission should be made to the bank within the legal submission period according to the date of issue on the cheque, and the cheque should be classified as a bounced cheque (Cheque Act No. 5941, Art. 3/8).

Due to the widespread use of postdated cheques in Turkish commercial life, the rate of bounced cheques has also increased over time. Prevention of bounced cheques is extremely important in terms of establishing an atmosphere of trust and stability in commercial life. Until today, in terms of doctrine and practice, more emphasis has been placed on the scope and magnitude of sanctions to be applied to bounced cheques in the realization of this objective (Can, 2015; Tekinalp, 2010; Öztan, 2016; Özgenç, 2010; Poroy, Tekinalp, 2013;Soydal, 2010; Ülgen, Helvacı, Kendigelen, Kaya, 2016). Despite the fact that Turkish law has been changed many times in this respect, the desired outcome has not been obtained so far.

The application of QR Code in cheques, which arose as a consequence of the integration of technological developments with economic and legal needs, promises the reduction (and even the elimination) of bounced cheques and forged cheques. QR Code application in cheques has introduced a significant innovation to commercial life, and became compulsory in Turkey since the beginning of 2017. There is not enough data on the execution of QR Code cheques, and there are limited number of studies and reviews. Therefore, it is not yet possible to reach definitive conclusions regarding the use of QR Codes. This study will primarily focus on the development of QR Code cheques in light of the changes that are made in Turkish law, accepting the $Q R$ Code as a compulsory element for the cheques and the operation of the QR Code cheque system. Then, a general overview of the system will be provided, and the aims, benefits, and deficiencies of this system will be evaluated.

\subsection{Development of QR code cheques}

The increase in bounced cheque rates despite imposed sanctions has led to a search of alternatives. In line with technological improvements, the facilitation of the recording and monitoring of commercial data and the infrastructure created in this regard have led to the idea that such technological conveniences can also be used in cheque payments.

QR Code application in cheques was developed by the Credit Reference Bureau (CRB) in cooperation with the Banks Association of Turkey and the Turkish Union of Chambers and Commodity Exchanges of Turkey. QR Code cheques, which were presented at the QR Code Cheques Introductory Meeting on June 4, 2015, were launched on June 15, 2015. The use of QR Code cheques is still optional and the cheques are arranged after the merchant presents a deed of consent to the bank indicating that the merchant is ready to share its cheque payment history with its commercial network.

QR Code cheques introduced in June 2015 received a lot of interest in application, and were preferred by nearly one hundred thousand account owners from 2015 until 2017, when the relevant legal regulation was implemented (“Karekodlu Çek 1 Milyonu Aştı”, 2017).

\subsection{Legal obligation of QR codes in cheques and its reasons}

Cheques are regarded among "bills of exchange" in Turkish law. Cheques are bills that are subject to strict formal conditions just like other bills of exchange, such as bills and notes. The qualification of a document as a cheque depends on the inclusion of certain elements implicated in law.

The obligatory elements of a cheque are listed in Article 780 of the Turkish Commercial Code No. 6102. Accordingly, it must include the word cheque, and the equivalent word for "cheque" if the bill is written in a language other than Turkish, money transfer for the unconditional payment of a certain price, trade title of the payee, i.e. "interlocutor", place of payment, the date and place of issue, and the 
signature of the drawer (the place of payment and place of issue are elements with alternatives). With the amendment made in this article with the law dated July 15, 2016 and numbered 6728, the use of QR Code cheques, which were optional until this date, have become mandatory starting from December 31, 2016, with the addition of QR Code and serial number to the abovementioned elements.

In the preamble of Law No. 6728, it has been stated that these changes were the result of the necessity of introducing new regulations for the purposes of a) ensuring the speed and security requirements that cheques necessitate, b) widespread payment by cheque, $c$ ) the foundation of cheque holders' protection due to the increase in bounced cheque rates.

In accordance with the amendment, after December 31, 2016, the banks in Turkey are not allowed to print and distribute cheque leaves that do not contain QR Codes. Cheque leaves printed before this date are still valid. Since the 11th Provisional Article of the Turkish Commercial Code clearly states that these elements shall not be looked for in cheques printed before December 31, 2016, the doubts that may arise on this issue have been eliminated. However, since most payees will not prefer to accept these cheques that are not covered by the QR Code system, this transition period is expected to happen faster in application.

QR Code requirement in cheques is only valid for cheques printed by the banks in Turkey. The absence of a QR Code (and serial number) in cheques printed by foreign banks does not affect the validity of the bill as a cheque.

Thus, new elements have been added to the obligatory elements of a cheque, which have been accepted without modification since the repealed Commercial Code No. 865 dated 1926 (Art. 608) (similarly, repealed Turkish Commercial Code No. 6762 dated 1956, Art. 692). Although Cheque Act No. 5941 cites the additional elements required to be present on a cheque, these rules are regulative, and the absence of the elements cited in this law is not an indication of the validity of the cheque.

Principles regarding the application of QR Code in cheques are determined by a communiqué issued jointly by the Ministry of Customs and Trade, and the Under secretariat of Treasury in accordance with Article 780/4 of the Turkish Commercial Code (Official Gazette dated December 31, 2016 and numbered 29935 (3rd Repetition)).

According to the Notification of the Execution of QR Code on Cheques, a QR Code refers to a two-dimensional barcode that can be printed as a square or rectangle on a cheque and which is a component of the cheque, based on the ISO / IEC 16022 International Symbology Specification-Data Matrix ECC 200 Version. This is also a barcode that allows access to and reporting of other information listed in the Article 780/2 of Law No. 6102 and in this notification (Art. 3/1-b). Cheques containing this element are called QR Code cheques.

A QR Code cheque is not a new type of cheque (Narbay, Güney, 2017). These are a new generation of cheques that arise from the addition of a new element ( $Q R$ Code) to the already existing cheques.

It should also be noted that QR Code cheques are different from the Certified (Provisioned, Blocked) Cheques. The QR Code does not contain information on whether it is a bounced cheque. For this reason, the scanning of the QR Code does not mean the cheque is certified or accepted.

\subsection{Operation of $Q R$ code cheque system}

In accordance with TCC Article 780/3, the QR Code scanning and information sharing system is created by Banks Association of Turkey Risk Center established in accordance with Law No. 5411 (additional article 1). With this regulation, the Risk Center is authorized to share the data in the system with companies that exchange information with the center.

Financial information sharing service in Turkey is provided by Credit Reference Bureau (CRB) established in 1995 with the participation of 9 leading banks in Turkey. CRB is the sole service provider of the Risk Center established by the Turkish Banks Association (Kredi Kayıt Bürosu, n.d.; Pulaşlı, 2017).

CRB carries out the sharing of financial information through a service platform called Findeks. All the data shared on this platform is stored in the data center of the CRB, which is audited by the Banking Regulation and Supervision Agency and independent audit companies (Findeks Hakkında, n.d.).

The QR Code cheques included in this system can be requested from all banks in Turkey allowed to give their customers a chequebook. In transactions where a QR Code cheque leaf is used, the payee can confirm the validity of the cheque leaf by scanning the QR Code on the cheque with an application 
while accepting the cheque, and can be informed about the past payment habits of the drawer along with the cheque report.

The function of QR Code does not end here. QR Code cheques and records of the filled in cheque contents may be queried by the transferee during each cycle. In this context, the cheque payee to whom a cheque has been made out must register the received cheque to this system (this regulation will enter into force on December 31, 2017 as stated in Article 3/10 of the Cheque Act, Article 76/1-f of the Law No. 6728). Cheques without data entry by the cheque holder shall not be void. However, the responsibility for the minimum amount for which the drawee bank is obliged to pay disappears for these cheques. On the other hand, the power of circulation for cheques that are not recorded in the system and therefore cannot be verified inevitably weakens.

With the registration of the cheque to the system, if there is a rasure, scrap, falsification or other fraud in the cheque text, they are becoming detectable together with the drawing (Pulaşll, 2017). In this respect, QR Code cheques are an important step in the prevention of forged cheques.

Registration of cheques presented to a beneficiary/cheque payee aims to prevent off the books transactions that are created in this sense. On the other hand, QR Codes will also make the number and amount of cheques belonging to the account holder that are not yet submitted to the bank, accessible by third parties. Thus, upon receipt of the necessary notification by the beneficiary, the payee will have the opportunity to make an assessment of the number and amounts of cheques in circulation belonging to the account owner with the help of the QR Code, and thus have the ability to make an assessment as to accept or reject the cheque (Law No. 6728, Preamble of Article 62).

With the provisions added to the Cheque Act, it is also clearly stated that the changes in the representatives of the cheque-issuing entity after the date on which the QR Code cheque is recorded in the system shall not remove the responsibility of the legal entity that is the owner of the cheque account (Cheque Act No 5941, Art. 3/10). Thus, the issues that may arise in practice due to the representation of legal entities are eliminated. In particular, in the case that the cheque account holder is a merchant, it has become possible to eliminate the problems related to agencies without authority due to the fact that the name, surname or trade name of the agents registered in the trade register can also be seen in the cheque report (Narbay, Güney, 2017).

\subsection{Information contained in QR code}

With the scanning of a QR Code, cheque payees can obtain detailed information about whether or not the cheque is in circulation, the accuracy of the information on the cheque leaf, and the cheque payment history of the drawer.

In this context, with QR Code the following is made available to third parties without the consent of the cheque account holder or the endorser;

- Name, surname or trade name of cheque account holder,

- Name, surname or trade name of the authorities registered with the trade registry in case the cheque account holder is a merchant,

- The total number of banks in which the cheque account holder has checking accounts,

- Number and amount of cheques of the account holder not submitted to banks,

- Number and amount of cheques issued and submitted to banks,

- Number and amount of cheques paid on submission within the past five years,

- Submission date of the first submitted cheque,

- Submission date of the last submitted cheque,

- Submission date of the last cheque paid on submission,

- Number and amount of "bounced" and still unpaid cheques within the past five years,

- Number and amount of "bounced" cheques that were later paid within the past five years,

- Submission date of the last "bounced" cheque within the past five years,

- Information on whether the cheque account holder is prohibited from opening a checking account, and if any, the date of the prohibition decision,

- Information on whether there is an injunction record on any cheque leaf,

If cheque account holder is a merchant, information on whether bankruptcy has been filed or not, and if so, the date of the decision (TCC Art. 780/2). 
By scanning the QR Code, it is possible to access this information which will be included in the cheque report as well as the cheque index. The cheque index is a ranking note that is the summary of the cheque report (Çek Endeksi, n.d.). A value between 0 and 1000 is specified here. A value of 1000 means that all the cheques of the drawer has been paid. Values lower than 1000 indicate that at least one of the drawer's cheques was a bounced cheque; the lower the value, the more irregular the payment of the drawer is.

The recording and sharing of such data is a legal exception in accordance with domestic law and the European Union regulations, in particular, the Turkish Law on the Protection of Personal Data No. 6698 , regarding the disclosure of personal data being subject to the consent and approval of the individual (Law No. 6698, Articles $5 / 2$ and 8/2). Although this exception is directly created by law, it can be said that consent and approval are initially given in this regard when a cheque account holder requests a chequebook with QR Code. When a cheque report is received, the approval of the drawer is not required. However, when a cheque index or a cheque report for another person is requested, an SMS is sent by the system to the account holder and only if this SMS is approved by the account holder, the user can see the reports.

Thus, the cheque report provides comprehensive information about the past payment habits of the drawer. The information contained in the QR Code is independent of applications such as removal of prohibition decisions or registry amnesty associated with loans.

\subsection{Benefits of the QR code system and expectations}

The benefits that can be observed with the implementation of the QR Code system and expected to emerge as the system becomes stable and widespread over time, can be discussed separately in terms of the effects on cheque-related parties and on commercial life.

\subsection{Benefits of $\mathrm{QR}$ code cheques in terms of cheque payees}

With the application of QR Code cheques, cheque payees will be able to view the cheque account holder's (drawer's) past payment habits with an application (namely Findeks) they download to their smartphone and tablet. The cost per report to be received by this system, which requires membership, has been determined to be rather small (up to a maximum of 0,60 TRY+VAT per report) although the amount varies depending on the number of reports received. It is not obligatory to be read the QR Code for the holder but a legally recognized authority (Narbay, Güney, 2017). Thus, if the cheque payee wants, he or she has the opportunity to make an assessment of whether or not to accept a cheque by easily obtaining information about past cheque payment habits of the other party.

The possibility of accessing information about a cheque and cheque account holder by receiving a cheque report does not belong only to the first bearer of the cheque. In addition to the first bearer, all the bearers who have taken over the cheque by means of endorsement can access this information in the same way. Thus, the bearer, who often does not know the account holder, can quickly and easily access important information that can confirm the account holder's credibility and whether the cheque is forged or not.

With QR Code cheques, the validity of the information contained in the cheque and whether there is an injunction decision on the cheque becomes easily verifiable. With this system, cheque payees have the ability to verify the cheque in their possession against the cheque information registered in the system. QR Code cheque system greatly reduces the circulation possibility of a forged or altered cheque.

Since it is also possible to access the information of individuals authorized to represent the merchant with QR Code cheques, the use of this system eliminates the risks associated with unauthorized representation.

\subsection{Benefits in terms of cheque account holder}

QR Code cheques also provide benefits for cheque account holders whose payments are regular. With QR Code cheque system, cheque account holders with regular payments in the past will have no difficulty in putting their cheques in circulation. For account holders who have the ability to 
easily reveal with a QR Code cheque query that their past pay-outs are regular, this situation gives them more prestige and increase their bargaining power.

This way, cheque account holders will be relieved of the burden of losing time with transactions such as giving additional collateral in their commercial relationships or providing additional information about themselves.

\subsection{Benefits in terms of Drawee bank}

The correspondent banks are obliged to reserve provisions for the minimum amount they are responsible for each cheque leaf they print (Law No. 5911, article 53), and to pay this minimum amount to the cheque bearer if the cheque bounces (Oğuz, 2014). If QR Code cheque application succeeds in reducing the rate of bounced cheques, the costs of correspondent banks regarding the payments they make for the minimum amounts they are responsible for will also decrease.

QR Code cheques significantly reduce the risk that the correspondent will pay a forged or altered cheque and thus be liable for it. Likewise, according to the Turkish Commercial Code Article $812 / 1$, the counterpart who has paid a forged or altered cheque, shall be liable for the resulting damage unless the cheque account holder is found wanting for not keeping the chequebook safe. With the benefits of $\mathrm{QR}$ Code cheques on preventing forgery, the possibility of banks making payments on forged cheques and being responsible for these cheques will decrease accordingly.

In commercial life, making payments with cheques instead of cash is of great importance to banks (Öztan, 2016). In this context, the increase in the number and amount of cheques, as a result of cheques earning the reputation they deserve, will result in the banks having more deposits and more profit in return.

\subsection{Benefits of QR code cheques in commercial life}

Cheques are bills on which the principle of abstraction of cause applies. This means that a validity of a cheque is irrelevant of the fundamental (internal) relationship that causes a cheque to be issued. As a result, cheques have public security (For the benefits of using cheques, see Öztan, 2016). With the introduction of QR Code cheques, this security has reached its final point in terms of cheques.

According to the Banks Association of Turkey Risk Center data, approximately 2 million cheques a month and over 20 million cheques a year are issued in Turkey. Until the end of 2016, about 3.5\% of these cheques bounced (Banks Association of Turkey Risk Center, n.d.). In this respect, the application of QR Code in cheques is an important step in the fight against bounced cheques.

Knowing that their cheque payment history can be easily accessed by the other party, merchants will make an extra effort to take the highest precautions for not delaying their cheque payments and to prevent possible neglect and forgetfulness. As a matter of fact, despite the fact that the cheque leaves printed prior to the QR Code application are also in circulation, the ratio of bounced cheques to total cheques in circulation has decreased about 1\% in the first 9 months of 2017 (Banks Association of Turkey Risk Center, n.d.).

The environment of trust that will be established in commercial life with the significant reduction of bounced cheques will have a positive effect on the country's economy as well. This, in turn, will facilitate economic growth and stability. On the other hand, this application will also be effective in terms of ensuring the international reputation of the cheques that are issued using the cheque leaves printed by Turkish banks.

QR Code cheques are also expected to assume an important role in the prevention of off the books trading in commercial life. In this context, since the cheque holder will be required to register the cheque to the system in order to ensure the security of the cheque, circulation of cheques will be easily monitored.QR Code cheques also offer solutions to some disputed issues in doctrine. It has been a topic of debate for many years whether the use of a cheque leaf is compulsory for issuing a cheque. The dominant view in this regard is that a cheque can be made out on any document without the use of preprinted cheque leaves printed by banks (Oğuz, 2014; Öztan, 2016; Ülgen, Helvacı, Kendigelen, Kaya, 2016). As the QR Code and serial number have become obligatory elements in cheques, the discussion on this topic has lost its importance. Since chequebooks can only be printed by banks, it has now become necessary for cheques to be made out by using pre-printed cheque leaves. However, cheques 
with an issuing date prior to December 31, 2016 should still be considered valid even though they were made out not using pre-printed cheque leaves.

\subsection{Discussion}

Although QR Code application on cheques provides easy access to information on the past payment habits of the cheque account holder, it does not guarantee subsequent payments. Here, only a prediction can be made from the financial information of the merchant's past. However, the provision of a collateral function in cheques with respect to the "acceptance ban" in accordance with their nature (TCC Art. 784/1) does not appear to be possible in the present system.

Similarly, one should not expect $Q R$ Code cheques to completely prevent cheque fraud. Especially in blank cheques, since the bearer will not be able to register a cheque with missing elements, there is a possibility of altering QR Code cheques by copying cheque leaves, or circulation of altered cheques by an unauthorized person. For this reason, it does not seem possible for blank cheques to be recorded to the system unless the essential elements of cheques are completed. Therefore, it is also not possible for blank cheques to benefit from the protection granted by the QR Code system.

With the easy access to financial information thanks to QR Code application, it is inevitable that the acceptance of cheque payments by other parties will become more difficult for people who have drawn a bounced cheque in the past. Although it can be said that the primary purpose of QR Code application is to access this information and authorize the payee to make this assessment, this outcome may lead to the end of the commercial lives of bonafide debtors.

However, it is still worth protecting the interests of the cheque holder more than that of the cheque account holder. At this point, the solidarity among the merchants gains more importance for the cheque account holder to continue its commercial life. Otherwise, it may be difficult for bonafide merchants who have experienced payment difficulties in the past to remain in commercial life. In such a case, those who have issued bounced cheques in the past will be in search of establishing new companies or using personal cheques.

It should be noted that this reservation significantly loses its importance due to that fact that the cheque reports that can be retrieved with QR Code cheques are only for the past five years. This makes it possible for someone who has been in financial difficulty for a period and who has then made bonafide transactions by improving their financial situation to be able to get rid of their past bad payments over time.

As mentioned earlier, the application of QR Code in cheques has actually emerged as a result of a need specific to Turkish law. At this point, the appropriateness of the provisions related to the practice of postdated cheques causing an increase in the rate of bounced cheques can be discussed.

Postdated cheques are considered valid in many countries (for example, the Swiss Code of Obligations Art. 1115/2, Convention Providing a Uniform Law for Cheques, Geneva 1931, Art. 28/2). In this system, while the submission is considered valid before the date of the written arrangement on the cheque in some countries, it is assumed that the drawee bank will be responsible for it in the case of submission before the date of arrangement in some other countries (For detailed information see Gençtürk, 2011). In Turkish law, it is accepted that the submission of the cheque to the drawee before the date of the written arrangement on the cheque shall be considered invalid by 31.12.2017 (Cheque Act, Provisional Art. 3/5) and in such a case, legal proceedings (execution follow-up) regarding the cheque (Cheque Act, Art. 3/8) and the penal provisions for bounced cheques cannot be applied (Cheque Act, Art. 5). This situation leads to more preference of cheques for futures in practice. In the doctrine, when the transaction cannot be made before the maturity in the all the transactions that are subject to maturity, the arrangements in this direction were justified with the thought that the awarding of a privileged status to cheques cannot be justified (Tekinalp, 2010). However, it should be noted that this result has overcome cheque's the qualification of the payment instrument.

If the arrangements leading to the development of the QR Code system are taken into account, it can be said that commercial life will gain speed and confidence with this new application. In this system, first of all, the drawee is relieved of the burden of conducting research about the account holder or whether the cheque is bounced or not. Nowadays, it is possible for consumers to learn all 
sorts of information about the product they bought by a QR Code, hence the integration of technological developments into commercial life is a positive development.

\subsection{Conclusions}

The application of QR Code on cheques has been developed in order to prevent bounced or forged cheques by making cheque payments safer. Through scanning the QR Code on cheques, information can be obtained about the past payment habits of cheque account holders and whether the cheque is a bounced cheque or not without any arduous investigations. With this in mind, it can be concluded that QR Code cheques are a novel innovation in commercial life.

The $\mathrm{QR}$ Code cheque system provides the most equitable balance of interest between the parties in cheque payments. Such that, in the one hand, this system allows the holder to foresee the possibility whether or not the cheque will be paid in the future, and on the other hand, it has become a reputation tool for account holders who make payments properly and it facilitates the circulation of cheques.

One should not expect QR Code cheques to completely eliminate bounced cheques. There are always risks in commercial life. The important thing is to minimize these risks and ensure an environment of trust. In achieving this, it is an important political step to increase transparency by taking advantage of technological developments and to prevent bounced cheques and forgery instead of foreseeing severe punishments and penalties for bounced cheques. Although its implications will be observed over time, the fact that QR Code is considered as a mandatory element in cheques issued in Turkey seems to be a good choice in terms of putting this practice into effect as soon as possible.

QR Code cheques have been developed as a result of a need specific to Turkish commercial life. Although this need is primarily due to the practice of post-dated cheques, it also meets a general need for the prevention of forged and altered cheques and easy access to the past payment habits of cheque account holders. In this respect, QR Code cheque application may be a model for foreign banks or legal systems that have similar problems in commercial life or want to make cheque payments more secure.

\section{References}

Banks Association of Turkey Risk Center. (n.d.). Retrieved from https://www.riskmerkezi.org/tr/istatistikler/23.

Can, M., (2015). Kıymetli Evrak Hukuku. Ankara.

Çek Endeksi. (n.d.). Retrieved from https://www.findeks.com/urunler/cek-endeksi.

Çöl, H. C., (2004). İleri Tarihli Çeke illişkin Sorunlar. Ankara Üniversitesi Hukuk Fakültesi Dergisi, 53(1), pp. 195-220.

Findeks Hakkında. (n.d.). Retrieved from https://www.findeks.com/findeks-hakkinda.

Gençtürk, M., (2011). Çek Kanununda Düzenlenen Yeni Sisteme Göre Ileri Tarihli Çekler Üzerine Bir Değerlendirme. Erzincan Üniversitesi Hukuk Fakültesi Dergisi, 15(1-2), pp. 119-159.

Güler, M., (1990). Sonraki Tarihli Çekler ve Uygulamada Ortaya Çıkan Sorunlar. Türkiye Barolar Birliği Dergisi(2), pp. 171-179.

Kredi Kayıt Bürosu. (n.d.). Retrieved from https://www.findeks.com/kredi-kayit-burosu.

Karekodlu Çek 1 Milyonu Aştı. (2017, January 28). Retrieved from http://www.hurriyet.com.tr/karekodlucek-1-milyonu-asti-40348970.

Narbay, Ş., Güney, Z., (2017). 6728 Sayılı Kanun'un Çeke ilişkin Hükümlerinin “Çekte Şekil Şartları” Bakımından Değerlendirilmesi. Terazi Hukuk Dergisi, 12(126), pp. 42-60.

Oğuz, S., (2014). Zayi Edilen Boş Çek Yapraklarının Mahkeme Tarafından İptaline Karar Verilip Verilemeyeceği Üzerine Bazı Düșünceler. Bankacılar Dergisi(90), pp. 33-50.

Özgenç, i., (2010). Yeni Çek Kanunu Üzerine Bir Değerlendirme. "5941 Sayılı Çek Kanunu" Paneli, (s. 6976). Ankara.

Öztan, F., (2016). Kıymetli Evrak Hukuku (20 ed.). Ankara.

Poroy, R., Tekinalp, Ü., (2013). Kıymetli Evrak Hukuku Esasları. İstanbul.

Pulaşlı, H., (2017). Kıymetli Evrak Hukukunun Esasları (5 ed.). Ankara. 
Soydal, O., (2010). 5237 Sayılı Türk Ceza Kanunu ve Yeni Çek Kanunu Işı̆̆ında Karşılıksıı Çek Keşide Etme Suçu. Ankara.

Tandoğan, H., (1981). Sonraki Tarihli Çekler ve Uygulamada Ortaya Çıkardıkları Sorunlar. Banka ve Ticaret Hukuku Araştırma Enstitüsü Dergisi, 11(2), pp. 63-94.

Tekinalp, Ü., (2002). Adalet Bakanlığı Taslağında ileri Tarihli Çekler. Çekler Hakkındaki 3167 Sayılı Kanunla ilgili Adalet Bakanlığı Taslağı ve Karşı Görüşler Sempozyumu, (pp. 41-48). Ankara.

Tekinalp, Ü., (2010). Yeni Çek Kanunu. "5941 Sayılı Çek Kanunu" Paneli, (pp. 7-12). Ankara.

Ülgen, H., Helvacı, M., Kendigelen, A., Kaya, A. (2016). Kıymetli Evrak Hukuku (10 ed.). İstanbul.

Yasan, M., (2014). Çek Kanunu Geçici m. 3 f. 1 Uyarınca Üzerinde Yazılı Düzenleme Tarihinden Önce ibrazı Geçersiz Olan Çekin Muhatap Banka Tarafından işsleme Konması (ve Özellikle Ödenmesi). TADD, 5(19), 321-354. 